\title{
The Effect Of Total Quality Management On Leadership: Case Of Nigeria
}

Ngozi Oriaku, (Email: noriaku@mail.ecsu.edu), Elizabeth City State University Ebere Oriaku, Elizabeth City State University

\begin{abstract}
In recent years, attempts to find solutions to political, economical, and social problems of developing nations have dominated the interest of developmental researchers. This paper, in effect, has taken the approach of finding the solutions to the problems facing poor leadership in many of the African countries, especially Nigeria. The paper is significant because it emphasizes on the cultural issues, lack of leadership skills, inadequate management operation of the nations, and lack of business competitive advantage. With the view of recommending a TQM model for implementing an effective leadership skills that has potential value-added to the masses, the paper provides Nigeria leaders with reliable tools for management. In addition, some specific elements have been highlighted and analyzed. The elements are: (1) leadership effectiveness, (2) leadership and Management commitment, (3) employee and individual involvement,(4) general public input, and (5) continuous improvement. With these elements chosen, the paper analysis is based on the effect of total quality management on leadership and sustainability of programs. An effective leader is one who points the way of success, who skills individuals who are as comfortable with change as they are with uncertainty, and one who has forward-thinking visionaries to lead the masses to believe and trust that they can improve their lack of efficiency and effectiveness in productivity. The paper recommends the use of total quality management on leadership and reorganization of operational managements in Africa nations, especially Nigeria.
\end{abstract}

\section{INTRODUCTION}

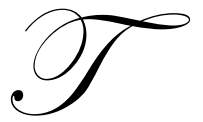

he inability of corporate managers and many leaders in Africa to effectively discharge concrete roles and the resultant failure of businesses and programs in today's corporate world have been linked together by analysts that one can easily regard them as cause and effect. In addition, the desire to avoid failure has dominated the minds of experts in various businesses, and researchers constantly seek ways of improving the quality of the programs, products, services, and leadership skills of leaders available to individuals in many of the African countries. This, of course, constitutes the major objective of having effective leaders in Nigeria who can apply and practice the total quality management process.

Schermerhorn defines leadership as the process of inspiring others to work hard to accomplish important tasks. Vadim Kotelnikov also defines leadership as the process of directing the behavior of others toward the accomplishment of some common objectives. Leadership is influencing people to get things done to a standard and quality above their norm, and doing it willingly." The role of a leader is to create followers, the task of a leader is to bring about constructive and necessary change. The responsibility of a leader is to bring about the change in a way that is responsive to the true and long-term needs of all stakeholders. The greatest source of power available to a leader is the trust that is derived from faithfully serving followers. Yet, it is difficult for many of the African leaders to demonstrate effective leadership.

According to Michael J. Stahl, intense global competition in recent years has caused managers and their organizations to experience and to continue to experience wrenching changes. Due to this fierce international competition, worldwide customers are now able to choose among several international competitors. As a result, customers have become increasingly demanding. Today, they require high quality, low prices and short delivery 
times, and tomorrow they will demand additional component value from their other chosen vendors. It is therefore evident that intense globalization and competition have been the stimulus for the spread of total quality management throughout the world. Managers of the $21^{\text {st }}$ century are concerned with delivering value-added to customers. This concept of customer value-added underscores the external focus of today's managers, which contrasts with the internally focused way of managing business and other organizations that prevailed in earlier decades of this century.

Stahl defines total quality management as a systems approach to management that aims to enhance value to customers by designing and continually improving organizational processes and systems. Stanly M. Cherkasky also defines total quality management as the creative problem-solving process of managing quality throughout the organization in order to improve its products, services, and operations. It includes the processes used to produce those goods and services.

As the definition of total quality management suggests, present day leaders and managers are involved in the management of systems and processes rather than in the supervision and control of people as they formerly were. Processes are groups of activities that take an input, add value to it, and provide an output to an internal or external entity. To put this in terms of leadership success, McGravie writes, "Leadership success is synonymous with organizational success," and corporate success, and thus leadership success is measured financially." This paper sees the Total Quality Management concept as a concept that if appropriately implemented to the leadership development and involvement of leaders in Africa and especially Nigeria's political and economical operation programs may result in wealth maximization, sustainability of programs through quality service, customer service, customer satisfaction and avoidance of the problems which are to be enumerated later in this paper's statement of the problem.

\section{STATEMENT OF THE PROBLEM}

In many years, the economical well-being of African countries has encountered numerous problems ranging from decline in currency and wealth, to inadequate investments development, to at least $2 \%$ of foreign direct investment. From reviewing various journals, articles, and textbooks, the problems of Africa nations, especially Nigeria has been attributed to the following factors:

1. Need for appropriate leadership skills;

2. Need for appropriate management style;

$3 . \quad$ Need for proper governance

4. $\quad$ Lack of morale;

5. Need for adequate communication skills

6. Inefficient operations;

7. $\quad$ Need for team spirit;

8. $\quad$ Need for adequate planning;

9. Need for adequate Entrepreneurial skills;

10. Lack of patriotism;

11. Need for conflict management skills;

12. Need for cross-cultural skills

13. Lack of trust.

14. Need for visionaries from leaders

Great efforts have been taken in finding solutions to improve poor leadership, poor sustainable programs and operational problems of Nigeria and the importance of Total Quality Management (TQM), since all the research effort on the importance of TQM had been centered on developed nations. Little had been done on TQM implementation in developing leaders and nations, and especially Nigeria, hence, it is a problem that this paper had to address, and the recommended solutions in this paper had to be based on strong probabilities. Some of the numerous problems facing Nigeria structures were caused by lack of adequate strategic and development planning and leadership by its employees, managers, leaders, and governmental agencies. 


\section{THE BRIEF HISTORICAL AND POLITICAL ECONOMY OF NIGERIA}

As a political entity, Nigeria came into formal existence in 1914 with the amalgamation of the northern and southern British protectorates. The colony and protectorate of Nigeria under a unitary administration presided over by a Governor-General was for administrative convenience divided into four parts: the eastern, western and northern provinces, and the colony of Lagos. In 1957, the eastern and western provinces were granted self-government while the other province did not attain similar status until 1959. Each of the three regions had a largely autonomous administration and its own budget. On October 1, 1960, Nigeria became independent from British rule and three years later became a Republic. The federal government has an exclusive powers in foreign relations, fiscal policies, commercial, defense, and security.

According to Schnitzer (1994), there are three things which African countries have in common. First, with only few exceptions, they were once colonies of European country; second, they are poor; and third, uncontrolled population growth limits their potential economic development and creates enormous social and political problems. The causes of these common characteristics vary according to different authorities. However, much of the causes of the common characteristics could be attributed to the desires of the colonizers. The colonizers placed a price preference where she could only serve two purposes. First, they provided a source of wealth for their owners in the ruling countries. Private companies were given monopoly rights by their governments to operate in the colonies and become the general media of commerce. The South Africa chartered company, owned by Cecil Rhodes, was given the right to develop the resources of Southern Africa. The discovery of gold in the South African Rand and diamonds at Kimberly made Rhodes one of the richest men in the world. Second, the African colonies served as markets for products of the ruling countries. According to Schnitzer, it was not until 1870 that British manufactured goods found a market in European countries. After 1870 Germany, France, Belgium and other countries had tried to satisfy their home markets; therefore, they began to produce a surplus for sale abroad. With increasing saturation of the European markets, all looked for more markets overseas, and for this purpose, Africa served admirably.

Nigeria the most populous Africa nations had a population of 137 million people as of 2005. Nigeria has basically a mixed economic system with government ownership in certain areas of economic activity. Public utilities, central bank, defense, and security systems are owned and operated by the government. There is a state owned national oil corporation, and the Nigeria's government has joint ventures with American and British oil companies.

\section{Political Structures}

The economic nerve center of the country was Lagos until the capital was moved to Abuja, yet Lagos is still the economic nerve center of the country. The quest for regional supremacy gave rise to serious troubles and political unrest around the country, and eventually a military government came into power in January 1966 as a result of a successful coup. The military government was short lived, and in July 1966, the same administration was overthrown in a counter coup. The next military government, in an attempt to dissuade the secession of the eastern region following hostilities around the country, subdivided Nigeria into 12 federal states in 1967. This administration ruled the country for nine years during which 1967-1970 civil war was fought. In July 1975, another coup d'etat forced a change in government. It did not take long before the new administration announced its program of relinquishing power and returned the rule of the country to a democratically elected government by October 1979. Prior to this, the government in 1976 had subdivided the country into 19 states. In October 1, 1979, after 13 years of military rule, a new constitution provided for a presidential system of government with a federal legislature (National Assembly) made up of a senate and a house of representatives. Important still is the fact that on December 31, 1983, the democratically elected government was overthrown in a bloodless coup d'etat, thus bringing another era of military rule. It is to be noted that all these political instabilities affected economic development (Kirk-Green, and Rimner, 1991).

As of the era of 19 states and the implementation of 1979 constitution, the senate had 95 members consisting of five senators from each of the 19 states, while representation is based on the population of each state. 
Unlike the bicameral legislature at the federal level, the state legislature (the House of Assembly) was unicameral and consisted of three times the total number of seats which the state had in the federal house of representatives. The states chief executive was the governor.

In this political structure, each state has extensive powers enabling it to draw up legislation, taking into account differences in local customs and the needs of each community. Financial assistance is received from the federal government to allow states to administer their substantial budgets and meet the costs of their individual investment programs. Foreign affairs, national defense, the general management of the economy and public finance (including the provision of national aviation, railways and port systems) are all within the exclusive authority of the federal government. Nigeria has gone through different types of leadership such as leadership under military rule by General Murtala Muhammed, Sani Abacha who took over from General Babangida after the annulment of the democratic election by which Abiola was projected the winner. In 1999, Olusegun Obasanjo became the democratic leader of a country that suffer economic stagnation and the deterioration of most of its democratic institutions. In addition, Nigeria has about 39 states including Abuja the federal capital of Nigeria.

Nigeria's present political structure is not the least important factor influencing the development of the functions of economic transition in the country. The fact that Nigeria is a federal state has several consequences. First, it creates a division of the country into clearly defined units, each with its own administration and each state government assumes a degree of control over the priorities of development in its region. Secondly, because of their greater influence, the main administrative and commercial cities in each state become more important in relation to other urban centers. At the same time, the coordination of the policies of various states with that of the federal government necessitates a total quality management between the state capitals and the federal capital, and, lastly, effective relationship between the states and the outside world is imperative for economical competitive advantage. Based on the presentation of a political structure modeled to the western democratic style, one will assume that Nigeria will enjoy economic growth which will lead to sustainable development. In addition, Nigeria is blessed with oil as a major natural resource which generates substantial revenue. The citizens learn fast and acquire skills that are impressive. Most of the educated Nigerians are in western nations, contributing substantially in the development of these western nations. The question then is "why is a nation so blessed suffering from poor economic development?" The finger points to the leadership style in existence. This paper takes the position that the need for the application of TQM will go a long way in remedying Nigeria's economic problems; and will position Nigeria to assume its rightful position and remain competitive in the global world. The theory of TQM will be revealed and recommendations on effective leadership style that will help Nigeria in attaining stronger economic position in the globe will be outlined.

\section{REVIEW OF LITERATURE}

Total Quality Management is an absolute must for any business organization and leaders who are in the $21^{\text {st }}$ century competition. Inherent to the paper is an understanding of the principles of Total Quality Management, the management leadership, and how they are related. To obtain this understanding, related literature was reviewed with the emphasis on understanding the concepts and the developments of Total Quality Management, application of Total Quality Management, quality improvement processes, management leadership and commitment, leadership effectiveness, continuous improvement, support, and involvement processes, and other actions which an effective leader and manager must do in order to achieve Total Quality Management objective. The organizational structure and operation of a nation or organization must be at par for success to be the result. The leadership success and the corporate success according to McGarvie, must be measured as financial and wealth for a nation and they are driven by two forces: integration and transformation. Integration is the force behind standardization, stability, and economy. It enables all of the disparate elements of a company or nation to fit together, work efficiently, and maximize profit or wealth. Transformation is the force behind differentiation and change. It enables a company or nation to set itself apart from its competitors or other nations and create new growth engines. Corporate success, however, is also a function of the effectiveness of the personal platform of its leader.

In the literature, Total Quality Management has been defined in many ways. Stahl, for instance, defines Total Quality Management as a systems approach to management that aims to continuously increase value to 
customers by designing and continuously improving organizational processes and systems. In this regard, Total Quality Management is viewed as a means of setting value for the customers, programs, and other entities, an integration of activities and processes across functions and departments, collaboration, and teamwork in an effort to achieve organizational goals. However, it could be explained as the product of the work of such American quality experts as Deming, Juran, Crosby, and the work of an important Japanese expert Ishikawa.

The movement towards Total Quality Management is a management system which was started by Frederick Taylor. This movement has been supported by numerous key individuals. Important participants in this development and a brief summary of their contributions are provided below:

Frederick Taylor has been credited with the development of a series of concepts that laid the foundation for work improvement using a systematic approach of analysis. Taylor indicates the following salient elements of his management theory: (1) each manager should clearly define large tasks which should take one day to complete, (2) the worker should have standard tools and conditions of work to complete the assigned task, (3) significant rewards should be paid for successful completion of the task, (4) penalties should be levied for failure to complete the assigned task. Indeed, total quality management has been a significant managerial issue longer than any other such issue in the last forty years. It has had a profound impact on the management of organizations throughout the world but especially on United States, Japanese, Canadian, and European firms. Total Quality Management is aimed at satisfying customers' needs. This is the position taken by many management experts. For example, Peter Drucker argued that the focus of business is not to make a profit but to respond to customer needs. If this is done, everything else, including profits, will fall into place. Once the customer's needs have been determined, Total Quality Management focuses on planning for quality, using statistical quality control techniques, promoting team problemsolving, creating a culture for quality improvement, making quality a part of the entire organization, and integrating quality into every requirement.

In the literature, many people credit Deming and Juran with teaching Japanese firms the quality control skills that have made Japanese firms such successful competitors with United States and European firms. Although both Deming and Juran offered advice to United States firms in the 1950s, they were disregarded because at that time, United States manufacturing firms' capabilities were the best in the world. By the 1980s, however, United States manufacturing practices had taken second place to those of the Japanese, and Deming and Juran were warmly embraced as champions of quality management. Much of Deming's philosophy for improving quality is captured in his fourteen points. In the 1980s, Phil Crosby also became a leading proponent of quality management. The idea of "zero defects" means exactly that there will be no defects.

Michael Barrier emphasized that Total Quality Management has become the most popular initials everywhere. Total Quality Management first took holds in big manufacturing companies that faced challenges from Japanese competitors and had acquired powerful reputations for high quality. He mentioned that the small businesses which supply big companies have felt the impact of those quality programs because the big companies have insisted that their small suppliers adopt quality programs of their own. This is important for continuous improvement of products, price, service, and defect-free products. The author made a strong comment stating that Total Quality Management among large firms does not just change how people do business, but it changes how everybody who deals with them does business. Customers today look at the quality of everything companies or small businesses do, and how they handle products, price, and deliveries.

Barrier further expresses that total quality management must have the following essential ingredients: (1) an intense focus on customer satisfaction, meaning the essence of Total Quality Management is to be customerdriven, according to the authors, (2) continuous improvement of leadership, products, and services, because total quality management is not a static concept; by eliminating chronic problems, it opens the way to never ending ideas and innovation, (3) new work relationships based on trust and teamwork ( Barrier, 1992). 


\section{MANAGEMENT LEADERSHIP}

According to Michael J. Stahl, leadership is the ability to influence people toward the accomplishment of goals. He asked a question "how important is leadership?" Leadership is especially important in a total quality organization because total quality involves dramatic changes to a new and improved way of doing business and managing operations. It takes influential leaders to cause followers to change (Stahl, 1995). The executive managers or leaders must play a pivotal role in the implementation of a TQM program in their countries and organizations. Therefore, it is the responsibility of government, executive managers and important leaders to lead, to dream, and to create their future for their countries and organizations. Stahl further stated that "a leader is one who commits people to action, who converts followers into leaders, and who may convert leaders into agents of change." Leaders are 'vision oriented' in their perspective; they create new ideas and spend their time with the action and with doing the right thing. Walton stated that Deming continually emphasized that leaders and management must lead the way, that only leaders can initiate the improvement of quality and productivity. The roles of the leader in the implementation of TQM programs are initiating change and implementation of change. A change of a country or organization requires an effective leader that is committed to its people with resources and money. Because of the breadth and magnitude of the commitment to implement a Total Quality Management transformation, the initiation of such a program must be a top down approach.

Crosby (1986) expressed that an organization's success or lack of it is directly due to the effectiveness of the leader. The initiation of change requires a positive leadership attitude as demonstrated by leader's vision, commitment, and attitude. Crosby and Deming stated that the degree of a country and its people response to the leader's vision is dependent upon the leader's attitude, and he stated that a nation or organization reflects an attitude that is generated by its leader. They further stated that regardless of what concepts are put in place or what systems are established, the attitude of citizens and employees toward quality is the clear result of what they see in the attitude of their leaders and executive management. This guidance from Cosby clearly places the responsibility for the implementation and success of Total Quality Management into the hands of organizational leaders and African leaders.

\section{TQM IMPLEMENTATION PROCESS}

The philosophies and techniques must be integrated into a coherent implementation plan. Total Quality Management is a top-down commitment. Leaders and top management must become enlightened and then pass the lamp of wisdom onward. The implementation process consists of five steps, which are:

\section{Develop A Compelling Vision}

African leaders must have a compelling reason that will sustain them and their countries for years to come. Thomas Berry describes quality management as a journey not a destination. Total quality management is not another program. Total quality management is a way of life that the African leaders must put their people and their customers first, eliminate barriers, and over-come whatever stands in the way of fulfilling the people interests and customer needs.

\section{Start Small}

It is unrealistic for Nigeria government and businesses to implement a nation wide quality management plan all at once. A single city, state, or region must first serve as a test site. In this stage, vision leadership is articulated and implemented. It is good to try to transform the test site completely before transporting the plan nation-wide or company-wide. Total Quality Management will have to work on all employees of the government or organization, not just the best or the worst.

African leaders and management must use the elements of the Deming cycle which are the Plan-Do-CheckAct (PDCA) cycle, in proving a systematic way to view continuous improvement. African leaders and top management must have constant communication with citizens and be willing to provide feedback in a timely 
manner. The PDCA cycle is useful throughout the life cycle of a program, product or service, and the "wheel" is shown in figure 1 .

Figure 1: Deming Wheel/PDCA Cycle

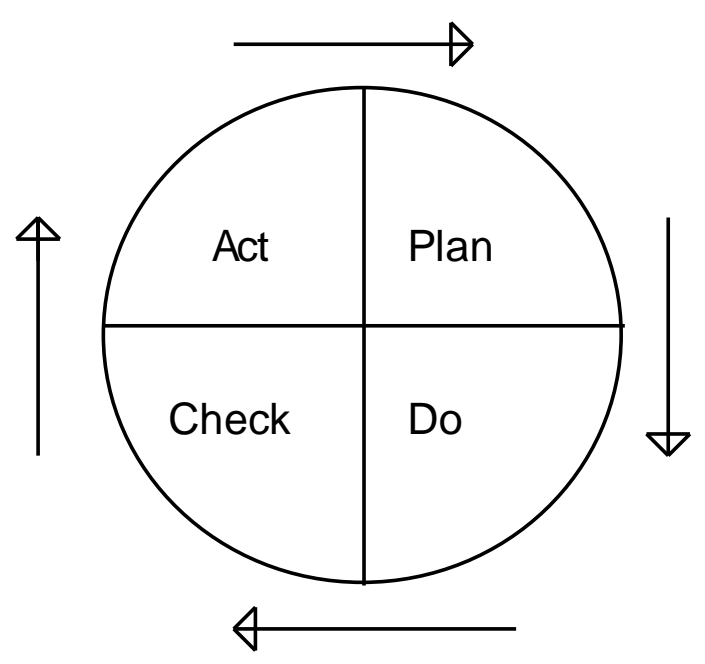

Source: Bruce Brocka and Suzanne Brocka, Quality Management Implementing the Best Ideas of the Masters, (New York: Irwin Publishing Co., 1992), 202.

\section{Become Obsessed}

Nigeria leaders and management must plan strategically and also become obsessed with implementing the vision and sweating out the details because these are what the people and customer sees, not wondrous corporate platitudes. Nigeria leaders and management must make abundantly clear that its people and customers are welcome, and that they are the core value of the nation. This ranges from stable security, encouraging foreign businesses to established well economical business, creating a friendly environment and well healthful society to produce a service and product of world class quality that the customer will be proud to own and find a pleasure to use the service and consume the product. Obsession to accomplish quality must be a top down approach. Employees must know who the top leaders and managers are personally. They cannot remain faceless.

\section{THEORETICAL APPLICATION OF TQM IN NIGERIA LEADERSHIP}

This paper outlines the key elements and other variables that describe an effective leader and TQM principles. The variables are: (1) leadership effectiveness, (2) leadership and management commitment, (3) employee and individual involvement, (4) general public input and (5) continuous improvement and effectiveness of a nation. The theoretical application of TQM explains the rationale behind the recommended TQM implementation in Nigeria leadership process.

\section{Leadership Effectiveness}

The leadership effectiveness generally concentrates on two important dimensions - the human element and the operation element. The most fundamental human goal of a leader's effectiveness is the changing of beliefs and attitudes of individuals in the nation. Before these changes can occur, however, it is important that people learn to trust each other. To achieve trust, certain procedures should exist, for example, open-communication, and empowerment should be used. The outcome of these activities can be an increased awareness of trust in others; this allows individuals in Nigeria to devote more time to goal accomplishment and less to corruptions. Improvement in 
these areas increases the likelihood that Nigeria can contribute more to the society at large and will also be able to obtain and utilize the scarce resources needed to ensure its future growth and existence.

\section{Leadership And Management Commitment}

Leadership and Management commitment are the active ingredients of TQM program implementation, which is necessary to demonstrate the level of leadership and management commitment to the country (Nigeria). A strong level of leadership commitment is required to overcome individual resistance.

\section{Employee And Individual Involvement}

TQM programs are based upon the involvement of vocal employees and individuals to be an active element in the improvement process of the country (Nigeria). Typically, TQM programs are developed to encourage participative leadership, to reduce the number of bureaucracy levels, to increase accountability, and to transfer some of the leadership responsibilities to the non-management individuals. Emphasis is placed on training important individuals in the Total Quality Management processes and in increasing their individual skill levels.

\section{General Public Input}

The government typically designs and produces policies that affect the public, without involving or communicating the policy with the public. TQM programs emphasize the need to communicates and involve important community leaders, institutional leaders, and religious leaders in the policy making. In TQM programs, customer needs are identified, and the organization, products, services, and processes are upgraded to achieve customer satisfaction, therefore, Nigeria leaders should follow the philosophy of TQM.

\section{Continuous Improvement}

After a TQM program is in place, it is important that the improvement of open-communication, responsibility, accountability, caring attitude, teamwork, and positive decision making processes continue until it's becomes a culture. Performance standards are constantly raised to new levels to promote the continuance of improvement. Nigeria leaders are expected to continue to improve in their decision making process and activities with proper TQM training.

\section{RECOMMENDATIONS}

facts:

Prior to the enumeration of the recommendations in this paper, it is important to point out some crucial

This paper seeks to provide a solution for Nigeria's leadership problems. The people and the governments wish to see a positive change in the operation of the country. The wish of the people is necessary because regardless of how good the plan to better leadership in Nigeria, many of the programs and operations of the country will not be effective, if the rulers are not willing to implement the changes.

Secondly, the suggested changes are not an end in themselves; they are means to an end of the problems. If the suggested changes are followed, it is strongly hoped that success will be achieved in terms of improving the Nigeria's image and relationship with other nations in leadership and performance, which will eventually position the country to be one of the top ten successful countries in using TQM.

The principal fact towards the workability of the recommendations is that the government must render one hundred percentage supports in implementing TQM in the country. Government should be willing to set up a climate whereby skilled or CEOs with excellent track records will be selected and will be allowed to perform their managerial duties and be evaluated based on their performance with TQM. As many businesses, institutions, and organizations aimed at increasing efficiency and maximizing profit, if the CEO is not making a profit due to his 
inability to perform and control the performance, then the CEO should be relieved of his/her duties instead of being kept because of tribal or political reasons. In the light of these, the following recommendations are made:

(1) There must be an encouragement of leadership from everyone, senior and lower officers in government, senior management to lower ranked employees, especially when these ideas are very necessary to the country, institutions, and organizations. Inadequate communication leads to poor performance, less acceptable service, a loss of revenue, and lack of patronage from the foreign businesses, foreign organizations, and customers worldwide. The government, CEOs, and other leaders must relay to all employees including the people of non-salary relationships, the philosophy of TQM, why it should be implemented, how it will help to reach their vision and the benefit it will bring over time to the country. Adequate communication on the advantages and disadvantages of TQM will help the leaders, employees, and customers overcome some fears of change.

As soon TQM is underway, attendance of improvement training by leaders, management, and nonmanagement employees will be an excellent motivator. Other motivational factors must be included as incentive package. However such motivational designs must be scrutinized to ensure that they do not defeat their objectives. Evaluation mechanism must be provided so that Nigeria leaders, managers, and other employees will always test or find out if TQM principles are being used as top priorities. Series of meetings with training opportunities should be in place. Excellent employees must be rewarded so as to induce all employees and citizens to strive for excellent performance.

(2) As days go by, so do we have the introduction of new technology and more modern approaches to work and services. Nigeria's leaders should be deeply involved in the training of other leaders, managers, principals, students, supervisors, and other levels of employees. Method of evaluation should be designed to show that the entities being trained are serious with the training and will incorporate ideas from the training into their different aspects of job performance.

(3) The introduction of implementation of TQM plan is in no way seen in Nigeria's past actions in transactions with other nations. For the country to be successful, top management break-through planning should be encouraged. The break-through plan helps in the processes, and in focusing quality improvement efforts on processes that can really make a difference. This might improve the position of Nigeria in a global competition which tends to reduce the negative perception of foreign businesses and foreign countries. TQM experts such as Deming, Juran, and Cosby recognize that TQM principles sometimes, or in many instances, are void of break through plans, and such have been observed to hurt their efforts. Efforts should guide against this outcome.

(4) The absence of teamwork which started from the government bureaucracy is a detrimental factor to Nigeria's performance. If people get together as a team and design policies and appoint who should implement the policies, all they need to do is devise an evaluation mechanism that will be used to assess the policy implementers performance. In this aspect, the team should have a strong focus on continuous improvement processes and quality improvement. Team leaders and facilitators should be people with training on total quality tools and effects. The team should focus on problem-solving skills and the enhancement of morale.

(5) The initial approach of TQM, without doubt costs money, time, and needs dedication. The government in this present situation should help to provide the team planners with financial backing and commit the leaders to devoting quality time with a built in reward in the plan. Nigeria's leaders in this case should be champions to the implementation of TQM principles. The application should be centered on solving problems of the country's operation. Results or outcome from any applied policy must be communicated to all community, institution, and religious leaders and feedback required from them. If complete success is not achieved, comments or feedback from general public, regardless of their level, may be very important weapons in arriving at the solutions.

(6) Quality culture is very important in any country and organization's utilization of TQM establishment. If the country is to achieve a quality leader servant, it is necessary that all involved in the policy making play a major part. In order for the nation wide effort to be achieved, Nigeria's leaders must provide quality culture. That is, leaders and management must provide the setting that stimulates quality. The setting consists of motivation, direction, and resources that each individual needs to achieve his/her quality goals. This culture requires that Nigeria's leaders and management take two steps. 
First, Nigeria's leaders must make it clear to everyone in the organization and to the country that they are committed to achieving quality. This message is to be communicated through public announcements, policies, directives, procedures, awards, and the like. Second, Nigeria's leaders and management must make resources available that are needed in every functional area, and on every organizational level to meet the quality and public expectations. It should be understood that the country and/or organization is in competition for effectiveness, recognition, profit, and dedication should be emphasized. There should be an emphasis on quality service and self-management.

The government should develop strategic implementation plan, devise a way to evaluate it, and be able to measure its returns. Proponents of a successful implementation plan should be rewarded, and such must be in the employment manual. Effective and efficient transmission and flow of ideas and factual data between people, departments, and divisions of organizations in the country is strongly recommended.

(9)

An important recommendation that is worth mentioning is the need for structural adjustment and total economic transformation. Regardless of the political and tribal problems that gave rise to the series of problems which implementation of TQM will be able to correct, it is reviewed that these problems were in effect when Nigeria's economy was strong and such factors did not affect the country's service performance. With the total decline in the economy and the loss of value of the naira- the national currency of Nigeria, the problems of the nation became magnified. The debt burden increased from $\$ 8.9$ billion in 1980 to $\$ 56.1$ billion in 2002 ; the debt was incurred on the assumption that oil revenues would continue to rise, thus facilitating its repayment and also due to the fact that the domestic currency commanded low value in foreign market. It takes an exorbitant sum to pay for the service rendered to the country abroad. This gave rise to some of the problems. Now that major portion of the debt has been relieved by some of the advanced nations, it should be the ultimate goal of Nigeria's leaders to apply TQM so that there will be no repeat of previous debt obligations. This will make the nation progressive and successful.

\section{CONCLUSION}

Effective leadership and total quality management demands readiness of the Nigerian people. The willingness and pride in the country and the government's willingness to provide the resources necessary to serve and satisfy the general public needs must be emphasized. However, this paper suggests that based on past leadership, a TQM program will be more effective in increasing the capabilities and performance of government, businesses, and the general public in Nigeria. The leaders in Nigeria should be willing to emphasize on the peopleoriented elements of management commitment and people's involvement, which will increase or change the process elements of continuous improvement and the people of Nigeria's satisfaction in improving the effectiveness of performance must be highlighted. It is imperative that Nigeria's leaders are not totally myopic to TQM concepts, but the major problem lies in implementation. This paper has unveiled the reasons for non-implementation and has concretely illustrated that the recommended TQM model might remedy the problems of Nigeria if properly implemented. Many authors agree with the writings of TQM experts such as Deming, Juran, and Crosby, which emphasized that the four key components of TQM program are essential for any nation planning to implement a TQM program. Deming strongly emphasized the importance of management leadership in his writings. Feigenbaum also indicated that the people in any nation are the most important participants in a TQM program, while Crosby agreed and concluded that leaders must emphasize that responsibility and accountability are the key elements to success. This, of course, is indicative of the lack of TQM implementation in sustainability of programs, organizational structure and operation of Nigeria. The paper also found that there were political, geographical, social, economic, and tribal constraints which negatively affected and still affect the performance of Nigeria.

\section{REFERENCES}

\section{Books}

1. $\quad$ Andersen, Arthur. (1992) Guide to Strategic Planning, Chicago: Subject AD 1945, Item 16.

2. Brocka, Bruce and Suzanne M. Brocka. (1992). Quality Management Implementing: The Best Ideas of the Masters. New York: Irwin Company. 
3. Carothers, G.H., G. M. Bounds, and M. J. Stahl. (1990). Management Leadership in M.J. Stahl and G. M.

Bounds eds., Competing Globally Through Customer Value: The Management of Strategic Suprasystems.

Westport, CT: Quorum Books.

4. Conway, William E. (1992). The Quality Search: The Right Way to Manage. Conway Quality, Incorporated: Nashua, New Hampshire.

5. Crosby, Phil B. (1994). Quality is Free: The Art of Making Quality Certain. New York: Mentor/Penguin.

6. Running Things, (1986) New York: McGraw-Hill Company.

7. Deming, Edward W. (1986). Out of the Crisis: Published by Massachusets Institute of Technology, Center for Advanced Engineering Study, Cambridge Massachusetts, MIT.

8. Drucker, Peter F. (1994). The Practice of Management. In The Management Challenge, ed. Higgins M. James, New York: Macmillan.

9. Higgins, James M. (1995). The Management Challenge. New York: Macmillan.

10. Imai, Masaaki. (1986) Kaizen. New York: Random House.

11. Ishikawa, Kaoru. (1990). Introduction to Quality Control. 3A Corporation Tokyo, Japan, Englewood Cliffs, N.J.: Prentice-Hall.

12. Juran, J. M., (1992) Juran on Quality by Design: The New Steps for Planning Quality into Goods and Services. New York: The Free Press.

13. Kirk-Green, Anthony and Douglas Rimmer. (1981). Nigeria Since 1970: A Political and Economic Outline. New York: Africana Publishing Company.

14. Kotter, John P. (1990) The Leadership Factor. New York: The Free Press.

15. Lewis, Arthur. (1990). Development Planning: The Essentials of Economic Policy. New York: Harper and Row.

16. Lewis, J. (1983). Long-Range and Short-Range Planning for Educational Administrators. Boston: Allen and Bacon, Inc.

17. McCune, S. D. (1986). Guide to Strategic Planning for Educators. Alexandria, Va.: Association for Supervision and Curriculum Development.

18. McLeod, Raymond Jr. (1993) Management Information Systems: A Study of Computer-Based Information Systems. New York: Macmillan Company.

19. Olaliku, A. (1979). Structure of the Nigeria Economy. New York: St. Martin Press.

20. Rampey, J., and H. Robert. (1992). Core Body of Knowledge Working Council: Perspectives on Total Quality in Reports of Total Quality Leadership steering Committee and Working Councils, Cincinnati, $\mathrm{OH}$ : Proctor and Gamble.

21. Richard, Tanner Pascale. (1992). Presentation to the Strategic Management Society.(London) translated by Higgins, James M. (1994) Management Challenge: An Introduction to Management. New York: Macmillan.

22. Robinson, Alan. (1991). Continuous Improvement in Operations: a Systematic Approach to Waste Reduction, Cambridge, Massachusetts: Productivity Press.

23. Savage, Edward W. (1992). The Fear of Change: Total Quality Management. New York: South-Western.

24. Schnitzer, Martin. (1994). Comparative Economic Systems. Cincinnati, Ohio: South-Western.

25. Scholtes, Peter R. (1988). An Elaboration on Deming's Teaching on Performance Appraisal. Madison, Wisconsin: Joiner Associates.

26. Stahl, Michael. (1995). Total Quality in a Global Environment. Cambridge, Massachusetts: Blackwell Company.

27. Stevenson, William J. (1993) Production and Operations Management 4th ed., Homewood, IL: Irwin.

28. Tenner, Arthur R., and DeToro J. Irving. (1992) Total Quality Management: Three Steps to Continuous Improvement. Cambridge, Massachusetts: Addison-Wesley 15.

29. The Principles of Scientific Management. (1992) Cincinnati, Ohio: South-Western.

30. Walton, Mary. (1990) The Deming Management Method. New York: Perigee Books.

31. World Bank Population Data Sheet, (1992) (Washington: Population Reference Bureau. 


\section{Journals, Magazines, And Newspapers}

1. Appleton, Elaine L. (1993) Bonding With Customers Through Better Service. Datamation 39, 69-70.

2. Armstrong, J. S. (1982) The Value of Formal Planning for Strategic Decisions. Strategic Management Review, 197-199.

3. Ashmore, Michael G. (1992) Better Information Means Better Quality, Journal of Business Strategy 13, 57-60.

4. Barrier, Michael. (1992) Small Firms Put Quality First, Nations's Business Review, 80, no. 5, 22-32.

5. Blankstein, Alan M. (1992) Lessons From Enlightened Corporations. Educational Leadership, 71-74.

6. Brigham, Steven E. (1993) Lessons We Can Learn From Industry. Change 25, no. 3, 30-32.

7. Bryce, Rex G. (1991) Quality Management Theories and Their Application. Quality, 15-17.

8. Buskirk, Donald D. (1993) Getting Familiar with Quality Terms. The Vocational Education Journal 68, no. 6, 46-49.

9. Crosby, Phil B. (1994) Quality Without Tears: The Art of Hassle-Free Management. Nation's Business 23, 13-71.

10. Deming, Edward W. (1980) NBC White Paper Entitled, If Japan Can, Why Can't We?, A 90 Minute Television Program, 1 June,.

11. Ferguson, Jeffrey M., and Robert A. Zawacki. (1993) Service Quality: A Critical Success Factor for IS Organizations, Information Strategy: The Executive's Journal 9, 24-27.

12. Garvin, David A., (1987) Competing On the Eight Dimensions of Quality. Harvard Business Review. vol: 65, 101-108.

13. Grant, Robert M., Rami Shani, and R. Krishnan. (1994) TQM's Challenge to Management Theory and Practice. Sloan Management Review, 25-34.

14. Kaufman, Roger, and Atsusi Hirumi. (1992) Ten Steps To TQM Plus. Educational Leadership Journal. vol: 50, no.3, 33-35.

15. Kotter, John P. (1990) What Leaders Really Do. Harvard Business Review, 103-111.

16. Lawler, Edward E., Albers S. Mohrman, and G. E. Ledford. (1992) Employee Involvement and Total Quality Management, Practice and Results. Fortune 1000 Companies Journal, 157-161.

17. Norman, Augustine R. (1990) TQM is the Key to Being a Winner. Martin Marietta Today, no.1, 2-4.

18. Radding, Alan. (1992) Quality is Job \#1._Datamation 38, 98-100.

19. Scholtes, Peter R. and Hacquebord H. (1988) Beginning the Quality Transformation. Quality Process, 2833.

20. Stanly, Cherkasky M. (1992) Total Quality for a Sustainable Competitive Advantage. Quality Review, 4-7. 